\title{
Mastery of Sumber Urip-1 farmer group in Malang Regency in the production and application of organic auxins and gibberellins
}

\author{
Moch. Agus Krisno Budiyanto ${ }^{\mathrm{a}, 1,{ }^{*},}$, Abdulkadir Rahardjanto ${ }^{\mathrm{b}, 2}$, Lud Waluyo ${ }^{\mathrm{a}, 3}$ \\ ${ }^{a}$ Department of Biology Education, Faculty of Teacher Training and Education, Universitas Muhammadiyah Malang, Indonesia \\ 'aguskrisno@umm.ac.id; 2abdkadir@umm.ac.id; 3/ud@umm.ac.id \\ *Corresponding author
}

\begin{tabular}{|c|c|}
\hline ARTICLE INFO & ABSTRACT \\
\hline $\begin{array}{l}\text { Article history } \\
\text { Received: } 20 \text { May } 2020 \\
\text { Revised: } 29 \text { August } 2020 \\
\text { Accepted: } 29 \text { August } 2020 \\
\text { Published: } 31 \text { August } 2020 \\
\text { Keywords } \\
\text { auxins } \\
\text { farmer groups } \\
\text { gibberellin } \\
\text { local potency } \\
\text { organic agriculture }\end{array}$ & $\begin{array}{l}\text { Organic agriculture was a manifestation of sustainable agriculture as stipulated in SDG } 2 . \\
\text { Therefore, farmer assistance activities were needed to implement organic agricultural } \\
\text { applications, namely the manufacture and use of organic auxins and gibberellins. This community } \\
\text { service aimed to provide assistance in the manufacture and use of organic auxins and gibberellins. } \\
\text { The method in implementing this activity was direct assistance and practice to solve problems. } \\
\text { The activity was held for three months, in Wonorejo Village, Poncokusumo District, Malang } \\
\text { Regency, East Java Province, with a partner named Sumber Urip-1 Farmer Group. The indicator } \\
\text { for the success of community service activities was that> } 75 \% \text { of the members (out of a total of } 20 \\
\text { people) can practice making organic auxins and gibberellins. To improve mentoring performance, } \\
\text { there was team synergy in the form of division of labor, cooperation patterns, and collaboration } \\
\text { patterns. Evaluation and monitoring of activities was carried out by holding morning meetings } \\
\text { every Friday. Through a series of activities, partners have mastered the methods of (1) } \\
\text { manufacturing and (2) using organic auxins and gibberellins. Products were branded with the } \\
\text { brands "Vignauksin" (from bean sprouts), "Fulicauksin" (from snails), and "Zeaberelin" (from corn). }\end{array}$ \\
\hline 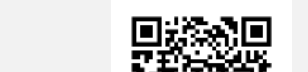 & $\begin{array}{l}\text { Partners' mastery of the methods of making and using organic auxins and gibberellins will support } \\
\text { organic farming efforts which were the embodiment of sustainable agriculture. }\end{array}$ \\
\hline
\end{tabular}

Copyright () 2020, Budiyanto et al This is an open access article under the CC-BY-SA license

\section{Check for updates}

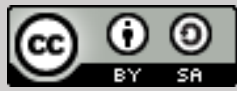

How to cite: Budiyanto, M. A. K., Rahardjanto, A., \& Waluyo, L. (2020). Mastery of Sumber Urip-1 farmer group in Malang Regency in the production and application of organic auxins and gibberellins. Journal of Community Service and Empowerment, 1(2), 64-72. doi: https://doi.org/ 10.22219/jcse.v1i2.12259

\section{PENDAHULUAN}

Pembangunan berkelanjutan telah menjadi fokus utama dari agenda pembangunan global yang tertuang dalam Sustainable Development Goals (SDGs) tahun 2015 (Nhemachena et al., 2018). SDGs diorientasikan pada terwujudnya keseimbangan dimensi pembangunan berkelanjutan, yaitu lingkungan, sosial, dan ekonomi. Dari 17 tujuan yang telah ditetapkan, terdapat tujuan kedua (SDG 2), yaitu "Tanpa Kelaparan: Tidak ada lagi kelaparan, mencapai ketahanan pangan, perbaikan nutrisi, serta mendorong budidaya pertanian yang berkelanjutan" (Ishartono \& Raharjo, 2016). SDG 2 bertujuan untuk mengakhiri kelaparan, kekurangan gizi, dan secara berkelanjutan menggandakan pendapatan dan produktivitas para petani (Rampa, Dekeyser, Alders, \& Dar, 2019). SDG 2 mengintegrasikan dan menghubungkan ketahanan pangan, nutrisi, dan pertanian yang berkelanjutan (Mollier, Seyler, Chotte, \& Ringler, 2018). Secara khusus, Indonesia telah menetapkan Undang-undang Nomor 13 Tahun 2011 yang berkaitan dengan "Sustainable Development Goals (SDG's) di Indonesia" (Prihanta, Zainuri, Hartini, Syarifuddin, \& Patma, 2020).

Sejalan dengan itu, di abad ke-21 ini tren pola gaya hidup sehat telah berhasil mendorong berkembangnya pertanian organik secara luas (Prihandarini, 2009). Pertanian organik merupakan salah satu alternatif menuju pembangunan 
pertanian ramah lingkungan dan berkelanjutan. Tujuan utama dari sistem pertanian organik adalah menghasilkan produk bahan pangan yang aman bagi kesehatan produsen maupun konsumen dan tidak merusak lingkungan. Pengertian organik menurut Food and Agricultural Oorganization adalah "a holistic production management system which promotes and enhances agroecosistern healyh, including biodiversity, biological cycles, and soil biological activity". Pertanian organik merupakan suatu sistem pertanian berkelanjutan yang diakui oleh European Commission dan Agricultural Council pada Konferensi Perserikatan Bangsa-Bangsa (Aertsens, Verbeke, Mondelaers, \& van Huylenbroeck, 2009; Jolly \& Norris, 1991).

Hasil penelitian sebelumnya telah menemukan bahwa persepsi masyarakat tentang pertanian hortikultura organik identik dengan pertanian sayuran dan buah yang tidak menggunakan pupuk buatan dan pestisida buatan (Budiyanto, 2007). Hasil penelitian tentang tipologi preferensi konsumen terhadap produk pangan organik di Kota Malang dapat dinyatakan bahwa: 1) Tipe pengambilan keputusan konsumen dalam memilih produk pertanian organik di Kota Malang adalah economic type (4\%), psychological type (13\%), consumer behaviour type (25\%), dan others type (58\%). Tipe lainlain sebagian besar karena alasan kesehatan, dan 2) Faktor-faktor yang mempengaruhi konsumen dalam memilih produk pangan organik di Kota Malang adalah faktor sosial (10\%), faktor personal (14\%), faktor psikologi (19\%), faktor kultural (5\%), dan faktor lain-lain (52\%). Faktor lain-lain sebagian besar karena faktor agama (Budiyanto, 2013). Dua penelitian ini mengindikasikan bahwa konsumsi produk pangan organik didasari alasan kesehatan.

Berdasarkan tren kebutuhan dan tuntutan masyarakat, maka pertanian organik sebagai wujud pertanian berkelanjutan harus dimaksimalkan. Maka dari itu, diperlukan berbagai kegiatan pemberdayaan dan pendampingan masyarakat (petani) dalam menerapkan pertanian organik (Budiyanto, Waluyo, \& Rahadjanto, 2020; Diwanti, 2018). Pertanian organik harus menerapkan penggunaan pupuk organik dan pestisida organik (Hamka et al., 2018; Puu, Saga, Djata, \& Mutiara, 2019). Selain itu, dalamm praktik pertanian diperlukan pula zat pengatur tumbuh (ZPT) sebagai upaya peningkatan pertumbuhan dan produksi tanaman (Pramita, Wandansari, \& Salim, 2018). Berdasarkan laporan kegiatan terdahulu, permasalahan petani dalam menerapkan pertanian organik adalah terkait pengetahuan dan keterampilan dalam pembuatan berbagai bahan pendukung pertanian organik baik pestisida (Budiyanto et al., 2020), pupuk, maupun hormon pertumbuhan organik.

Mitra dalam kegiatan ini adalah Kelompok Tani Sumber Urip-1 yang berada di Desa Wonorejo Kecamatan Poncokusumo Kabupaten Malang Provinsi Jawa Timur. Desa ini berada di timur laut Kota Malang dan berbatasan dengan Kabupaten Probolinggo (Lereng Gunung Bromo-Tengger), menjadi salah satu sentra produksi pangan organik di Kabupaten Malang.

Pada tahun 2015, Desa Wonorejo mempunyai jumlah penduduk sebesar 4.271, dengan jumlah laki-laki sebanyak 1928 orang dan perempuan sebanyak 2343 orang. Sebagain besar penduduk bekerja sebagai petani dan peternak. Dari 1.925 orang petani di Desa Wonorejo, sebagian besar (1254 orang atau 65,14\%) menjadi petani atau terlibat dalam produksi pangan organik. Para petani tersebut diorganisasi dalam Kelompok Tani Sumber Urip-1. Kelompok Tani Sumber Urip-1 mempunyai potensi untuk berkembang di masa-masa mendatang. Kelompok Tani Sumber Urip-1 mempunyai tujuan memproduksi pangan organik secara berkelanjutan melalui implemetasi pertanian organik.

Pertanian organik telah berjalan dan mulai produktif di Desa Wonorejo. Produk organik yang paling banyak dihasilkan adalah padi dan sayuran seperti, kol, gubis, tomat, kacang panjang, bayam, sawi, kacang panjang, cabai, dan bawang merah. Petani telah menggunakan pupuk organik padat, pupuk cair, pupuk kotoran sapi, kompos, insektisida oganik, fungisida organik, dan herbisida organik tetapi petani masih menghadapi masalah penggunaan zat pengatur tumbuh (ZPT). ZPT yang dimaksud adalah auksin dan giberelin organik. Kendala penggunaan auksin dan giberelin, yaitu suplai auksin dan giberelin kadang-kadang tidak lancar dan harganya mahal. Padahal di Desa Wonorejo terdapat potensi hayati yang dapat digunakan bahan pembuatan auksin dan giberelin organik, misalnya daun sirih, jahe, bawang putih, kunir, kencur, daun cengkeh, bunga kertas, bunga bougenville, dan lain sebagainya.

Secara spesifik setelah dilakukan diskusi/musyawarah dengan mitra, maka permasalahan mitra secara konkret dan menjadi prioritas yang harus ditangani adalah sebagai berikut, (1) mitra tidak menguasai metode pembuatan auksin dan giberelin organik berbasis pada potensi lokal dan (2) mitra tidak menguasai metode penggunaan auksin dan giberelin organik sesuai bahan baku lokal. Oleh karena itu, tujuan pengabdian ini adalah melakukan pendampingan pembuatan dan penggunaan auksin dan giberelin organik di Kelompok Tani Sumber Urip-1 Kabupaten Malang. Kegiatan pengabdiandan tentu saja artikel ini-berkontribusi dalam memberikan alternatif-alternatif kegiatan yang dapat dilakukan dalam mendukung upaya pencapaian SDG poin kedua (SDG 2).

\section{METODE}

Metode dalam pelaksanaan kegiatan pengabdian ini adalah pendampingan dan praktik langsung untuk menyelesaikan permasalahan sebagaimana tersaji pada Tabel 1. 
Tabel 1. Permasalahan, solusi, dan bentuk partisipasi mitra

\begin{tabular}{|c|c|c|c|}
\hline No & Permasalahan & Solusi & Partisipasi Mitra dalam Kegiatan \\
\hline 1 & $\begin{array}{l}\text { Mitra tidak menguasai metode } \\
\text { pembuatan auksin dan giberelin } \\
\text { organik }\end{array}$ & $\begin{array}{l}\text { Pelatihan pembuatan auksin dan } \\
\text { giberelin organik dari bahan } \\
\text { lokal }\end{array}$ & $\begin{array}{l}\text { - Berperan aktif dalam penyiapan alat/bahan } \\
\text { - Berperan aktif sebagai peserta pelatihan }\end{array}$ \\
\hline 2 & $\begin{array}{l}\text { Mitra tidak menguasai metode } \\
\text { penggunaan auksin dan giberelin } \\
\text { organik }\end{array}$ & $\begin{array}{l}\text { Pelatihan dan pendampingan } \\
\text { penggunaan auksin dan } \\
\text { giberelin organik }\end{array}$ & $\begin{array}{l}\text { - Berperan aktif dalam penyiapan alat/bahan } \\
\text { - Berperan aktif sebagai peserta pelatihan } \\
\text { dan pendampingan }\end{array}$ \\
\hline
\end{tabular}

Kegiatan pengabdian ini dilaksanakan dalam kurun waktu tiga bulan, yang dilaksanakan di Desa Wonorejo Kecamatan Poncokusumo Kabupaten Malang Propinsi Jawa Timur, dengan mitra adalah Kelompok Tani Sumber Urip-1. Indikator yang ditetapkan untuk melihat keberhasilan kegiatan pengabdian adalah $>75 \%$ anggota (dari total 20 orang) dapat mempraktikkan pembuatan auksin dan giberelin organik. Menurut Shofi dan Putri (2020), kegiatan pengabdian dinyatakan berhasil apabila pengetahuan dan keterampilan mitra terkait topik yang menjadi fokus telah meningkat.

Adapun pembagian kerja dalam pelaksanaan pengabdian ini adalah ketua tim bertugas menyusun deskripsi kerja anggota tim dan mahasiswa yang selanjutnya dikaji dan disempurnakan dalam rapat koordinasi. Dalam tingkatan teknis disepakati Ketua Tim bertugas untuk menyiapkan bahan-bahan akademik, pengurusan izin dan lobi program, serta mengkoordinasikan semua kegiatan. Anggota Tim bertugas mengkoordinasikan penyiapan alat, bahan, sarana pendukung, serta membangun partisipasi masyarakat/kelompok, terlibat aktif dalam setiap kegiatan, melakukan monitoring dan evaluasi kegiatan. Dalam pelaksanaan kegiatan juga dibantu oleh sepuluh mahasiswa yang sebelumnya terlebih dahulu diberi pembekalan.

Dalam upaya meningkatkan kinerja kegiatan pendampingan pembuatan dan penggunaan auksin dan giberelin ini, maka telah disepakati dan dibangun sinergisme tim dalam bentuk pembagian kerja, pola kooperasi, dan pola kolaborasi. Evaluasi dan monitoring kegiatan dilakukan dengan mengadakan morning meeting pada hari jum'at setiap minggunya.

Di sisi lain secara bersama-sama (Ketua Tim, Anggota Tim, Mahasiswa, Ketua Kelompok Tani, dan Anggota Kelompok Tani) melakukan monitoring dan evaluasi sesuai dengan jadwal yang telah ditentukan. Hasil monitoring dan evaluasi tersebut selanjutnya digunakan landasan dalam upaya meningkatkan kinerja program yang kemudian diikuti dengan redesain program dan redistribusi tugas antara Ketua Tim, Anggota Tim, dan Mahasiswa. Apabila ditemukan hambatan atau ketidaktercapaian indikator maka dilakukan optimasi program dengan cepat.

\section{HASIL DAN PEMBAHASAN}

Hasil yang dicapai dalam kegiatan pendampingan pembuatan auksin dan giberelin organik di Kelompok Tani Sumber Urip-1 Desa Wonosari Kecamatan Poncokusumo Kabupaten Malang adalah sebagai berikut.

\section{Pelatihan Pembuatan Auksin dan giberelin Organik dari Bahan Lokal}

Hasil kegiatan pelatihan pembuatan auksin dan giberelin seperti disajikan pada Tabel 2. Sementara itu, proses pembuatan pembuatan auksin dan giberelin organik serta praktik penggunaannya disajikan pada Gambar 1 dan Gambar 2.

Tabel 2. Kegiatan pelatihan

\begin{tabular}{ll}
\hline Aspek & Keterangan \\
\hline Peserta & 5 orang anggota Kelompok Tani Sumber Urip-1 Desa Wonorejo Kecamatan Poncokusumo Kabupaten Malang \\
\hline Fasilitator & Dr. Moch. Agus Krisno Budiyanto, M.Kes. \\
& Dr. Abdulkadir Rahardjanto, M.Si. \\
& Dr. Lud Waluyo, M.Kes. \\
\hline Co-Fasilitator & 10 Mahasiswa Pendidikan Biologi FKIP UMM. \\
\hline Tempat & Rumah Ketua Kelompok Tani Sumber Urip-1 \\
\hline
\end{tabular}

Kegiatan dilaksanakan selama dua minggu. Materi yang disampaikan adalah cara membuat auksin dan giberelin organik. Metode yang digunakan adalah fasilitator menjelaskan dan mempraktekan cara membuat auksin dan giberelin organik dan fasilitator mendampingi produksi auksin dan giberelin organik. Adapun bentuk partisipasi mitra adalah berperan aktif dalam penyiapan alat, bahan, dan tempat dan berperan aktif dalam pembuatan auksin dan giberelin organik. Indikator keberhasilan yang dicapai adalah 100\% mitra memahami dan dapat melakukan produksi auksin dan giberelin organik. 


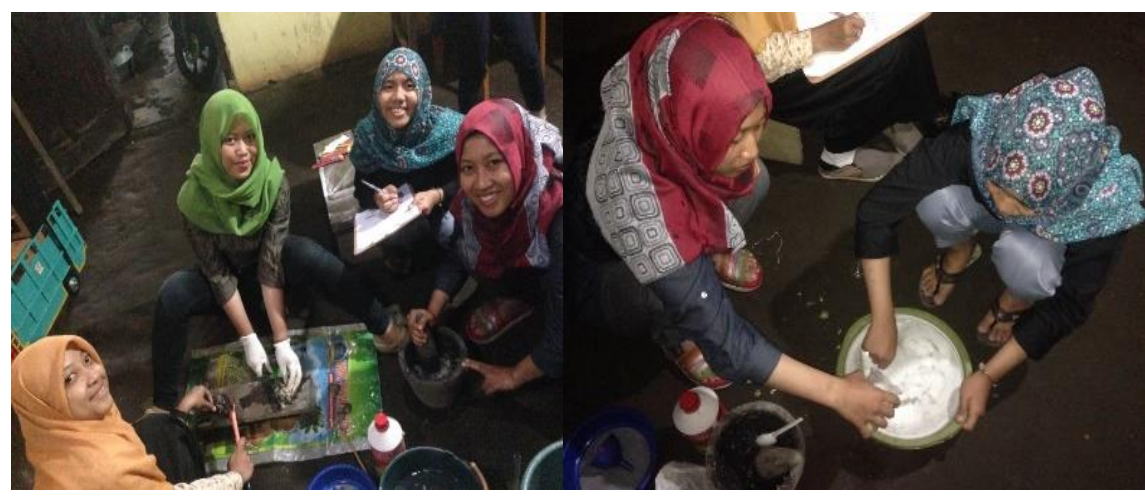

Gambar 1. Proses pembuatan auksin dan giberelin organik

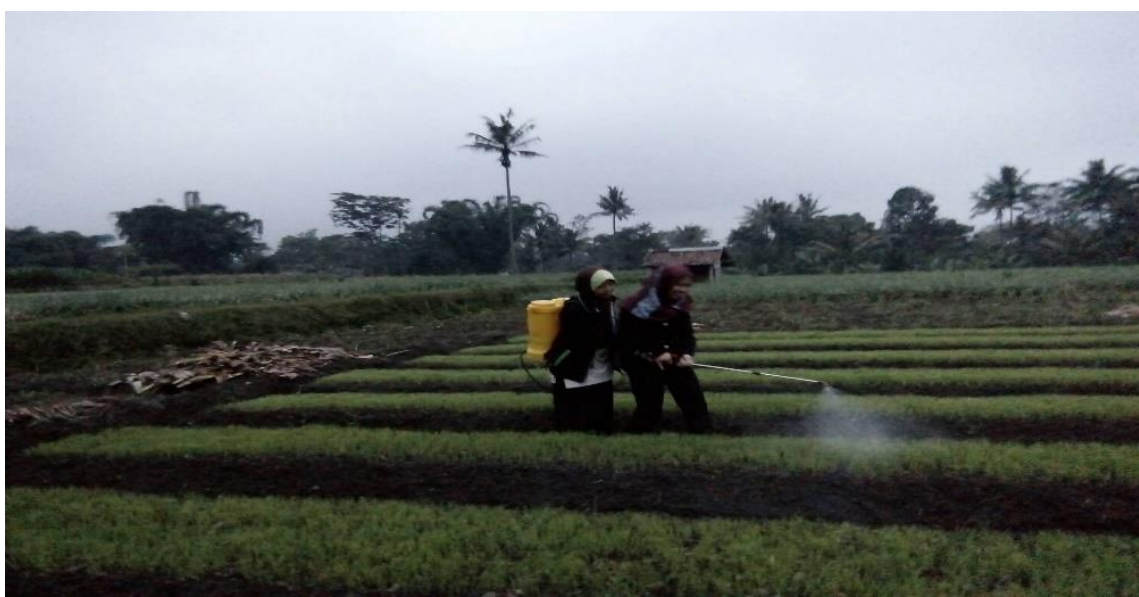

Gambar 2 Proses pengunaan auksin dan giberelin organik

Adapun cara membuat auksin organik "Vignauksin" adalah: 1) menyiapkan alat dan bahan yang akan digunakan, 2 menimbang kecambah dengan berat $1 \mathrm{~kg}$, 3) menimbang gula pasir seberat $250 \mathrm{gr}$, 4) menumbuk kecambah menggunakan lumpang dan alu sampai halus, 5) memindahkan kecambah yang telah halus kedalam baskom, 6) menuangkan air kelapa kedalam wadah baskom sebanyak 5 liter dengan alat ukur berupa beaker glass 7) memasukkan gula sebanyak $250 \mathrm{gr}$ kedalam baskom, 8) memasukkan bio aktivator berupa moebilin sebanyak $200 \mathrm{ml}$ kedalam baskom, 9) mengaduk larutan kearah kiri,10) memasukkan larutan kedalam jurigen, dan 11) mengaduk larutan dalam jurigen ke arah kiri.

Cara membuat auksin organik "Fulicauksin" adalah: 1) menyiapkan alat dan bahan yang akan digunakan, 2) menimbang bekicot sampai berat $1 \mathrm{~kg}$, 3) menimbang gula pasir seberat $250 \mathrm{gr}, 4)$ menumbuk perut dan cangkang bekicot menggunakan lumpang dan alu sampai halus, 5) memindahkan bekicot yang telah halus kedalam baskom, 6) menuangkan air kelapa kedalam wadah baskom sebanyak 5 liter dengan alat ukur berupa beaker glass, 7) memasukkan gula sebanyak $250 \mathrm{gr}$ kedalam baskom, 8) memasukkan bio aktivator berupa moebilin sebanyak 200 ml kedalam baskom, 9) mengaduk larutan kearah kiri, 10) memasukkan larutan kedalam jurigen, dan 11) mengaduk larutan dalam jurigen ke arah kiri.

Cara membuat giberelin organik "Zeaberelin" adalah: 1) menyiapkan alat dan bahan yang akan digunakan, 2) menimbang jagung muda sampai berat $1 \mathrm{~kg}, 30$ menimbang gula pasir seberat $250 \mathrm{gr}$, 4) menumbuk jagung muda menggunakan lumpang dan alu sampai halus, 5) memindahkan jagung muda yang telah halus kedalam baskom, 6) menuangkan air kelapa kedalam wadah baskom sebanyak 5 liter dengan alat ukur berupa beaker glass, 7) memasukkan gula sebanyak $250 \mathrm{gr}$ kedalam baskom, 8) memasukkan bio aktivator berupa moebilin sebanyak $200 \mathrm{ml}$ kedalam baskom, 9) mengaduk larutan kearah kiri, 1) memasukkan larutan kedalam jurigen, dan 11) mengaduk larutan dalam jurigen ke arah kiri.

\section{Pendampingan Penggunaan Auksin dan giberelin dari Bahan Lokal}

Hasil kegiatan pendampingan pembuatan auksin dan giberelin seperti disajikan pada Tabel 3 dan Tabel 4. 
Tabel 3. Kegiatan pendampingan tahap 1

\begin{tabular}{ll}
\hline Aspek & Keterangan \\
\hline Peserta & 5 orang anggota Kelompok Tani Sumber Urip-1 Desa Wonorejo Kecamatan Poncokusumo Kabupaten \\
& Malang \\
Fasilitator & Dr. Moch. Agus Krisno Budiyanto, M.Kes. \\
& Dr. Abdulkadir Rahardjanto, M.Si. \\
& Dr. Lud Waluyo, M.Kes. \\
\hline Co-Fasilitator & 10 Mahasiswa FKIP-Biologi UMM. \\
Tempat & Lahan Kelompok Tani Sumber Urip I \\
\hline
\end{tabular}

Kegiatan dilaksanakan selama dua minggu. Materi yang disampaikan adalah cara menggunakan auksin dan giberelin organik. Metode yang digunakan adalah fasilitator menjelaskan dan mempraktekan cara menggunakan auksin dan giberelin dan fasilitator mendampingi penggunaan auksin dan giberelin organik.. Adapun bentuk partisipasi mitra adalah berperan aktif dalam penyiapan alat, bahan, dan tempat dan berperan aktif dalam pembuatan auksin dan giberelin organik. Indikator keberhasilan yang dicapai adalah 100\% mitra memahami dan dapat menggunakan auksin dan giberelin organik.

Tabel 4. Kegiatan pendampingan tahap 2

\begin{tabular}{ll}
\hline Aspek & Keterangan \\
\hline Peserta & 10 orang anggota Kelompok Tani Sumber Urip-1 Desa Wonorejo Kecamatan Poncokusumo Kabupaten \\
& Malang \\
Fasilitator & Dr.H.Moch. Agus Krisno B,M.Kes. \\
& Dr. Abdulkadir Rahardjanto,M.Si. \\
& Dr. Lud Waluyo, M.Kes. \\
Co-Fasilitator & 10 Mahasiswa FKIP-Biologi UMM. \\
Tempat & Rumah Ketua Kelompok Tani Sumber Urip I \\
\hline
\end{tabular}

Kegiatan dilaksanakan selama satu minggu. Materi yang disampaikan adalah good practice pelatihan dan pendampingan pembuatan, penggunaan, packaging, labeling auksin dan giberelin organik. Metode yang digunakan adalah fasilitator menjelaskan good practice pelatihan dan pendampingan pembuatan, penggunaan, packaging, labeling , dan marketing auksin dan giberelin organik. Adapun bentuk partisipasi mitra adalah berperan aktif dalam penyiapan tempat, fasilitas pendukung dan berperan aktif sebagai peserta deseminasi. Indikator keberhasilan yang dicapai adalah 100\% mitra memahami dan tertarik mengimplementasikan good practice pelatihan dan pendampingan pembuatan, penggunaan, packaging, labeling, dan marketing auksin dan giberelin organik.

\section{Deseminasi good practice}

Adapun produk yang dihasilkan bersama dengan mitra terdiri atas "Vignauksin" dari taoge, "Fulicauksin" dari bekicot, dan "Zeaberelin" dari jagung, sebagaimana disajikan pada Gambar 3.

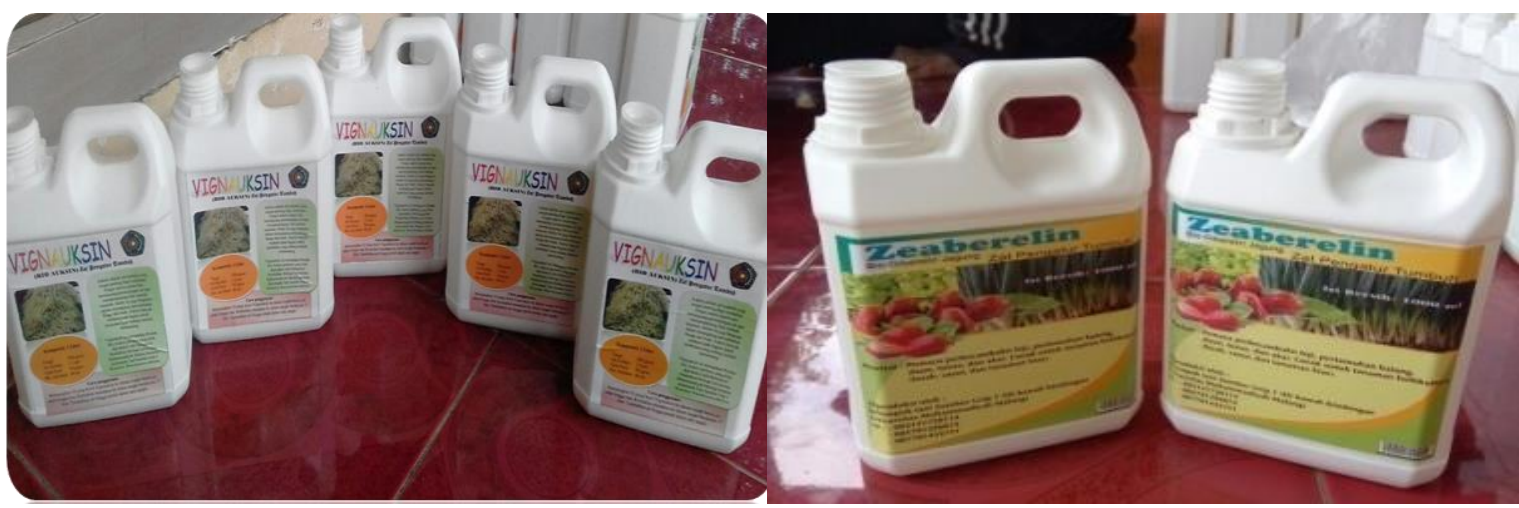

Gambar 3. Produk auksin dan giberelin organik "Vignauksin” (dari taoge), “Fulicauksin” (dari bekicot), dan “Zeaberelin” (dari jagung)

Produk yang telah dihasilkan selanjutnya diserahkan kepada mitra untuk dimanfaatkan atau dimaksimalan. Adapun proses penyerahan secara simbolis seperti disajikan pada Gambar 4. Mitra sangat antusias dan semangat menerima berbagai produk yang dibagian untuk kemudian mereka aplikasikan dalam pertanian organik mereka. 


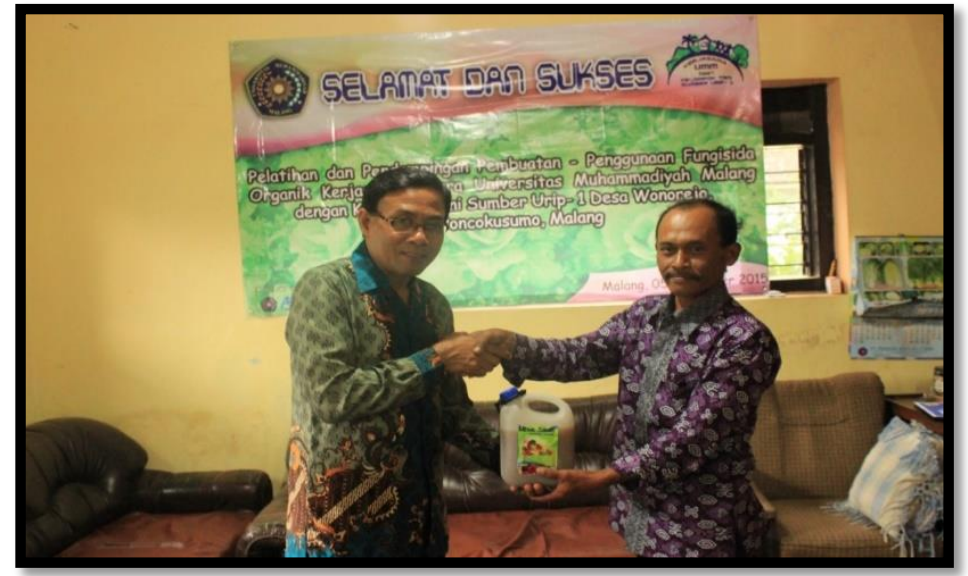

Gambar 4. Penyerahan produk auksin dan giberelin organik kepada ketua kelompok tani Sumber Urip-1

SDGs di Indonesia akan terlaksana dengan baik apabila terbuka ruang partisipsi bagi masyarakat sipil (Ngoyo, 2015; Susanti, 2018), terutama dalam mewujudkan SDG 2, yaitu "Mengakhiri kelaparan, mencapai ketahanan pangan dan nutrisi yang lebih baik dan mendukung pertanian berkelanjutan." (Wahyuningsih, 2018). Pemerintah tentu tidak akan mampu memenuhi pencapaian SDGs tanpa adanya kerjasama dan keterlibatan berbagai pemangku kepentingan (Hatta, Jaelani, \& Taufany, 2020). Pelibatan masyarakat dalam skala luas akan mempercepat reorientasi kebutuhan ekonomi sehingga mendorong pertumbuhan manusia, keberlanjutan bumi, dan sekaligus kesejahteraan masyarakat (Panuluh \& Fitri, 2016). Setiap orang perlu mengembangkan rasa peduli dan memiliki kesadaran diri mengenai potensi yang dimiliki untuk berkontribusi mensukseskan SDGs (Juned, Kusumastuti, \& Darmastuti, 2015).

Sektor pertanian berkontribusi signifikan terhadap pencapaian target SDGs yakni untuk kesejahteraan manusia dan planet bumi. Pertanian menjadi leading sektor bagi SDGs. Salah satu aspek yang sangat penting ada pertanian organik. Menurut Indriana, A Kinseng, dan Adriana, (2016) pertanian organik merupakan salah stau implementasi atau perwujudan pertanian berkelanjutan. Sehubungan dengan itu, menurut Mustafa (2018) pertanian organik sebisa mungkin hanya menggunakan pupuk, pengendali hama, dan hormon pertumbuhan dan enzim dari zat-zat yang berbasis biologis.

Pada kegiatan pengabdian ini, kami melakukan pendampingan pendampingan pembuatan auksin dan giberelin organik di Kelompok Tani Sumber Urip-1 Desa Wonosari Kecamatan Poncokusumo Kabupaten Malang. Hal ini mengingat selama ini, masyarakat sangat bergantung pada penggunaan ZPT yang non-organik (sintetik).

Setiap tumbuhan memiliki struktur dan morfologi tentunya, hal tersebut terjadi karena dipengaruhi oleh faktor intrasel yang ada dalam gen sebagai bentuk dalam pembawa sifat atau dikenal dengan faktor hereditas. Selain dari faktor intrasel, dikenal juga faktor intersel yang berupa zat tumbuh yang disebut dengan hormon tumbuh yang ada pada tumbuh-tumbuhan. Hormon-hormon tumbuhan tersebutlah yang mengatur arah dan kecepatan, kapan tumbuhan berbunga, buah akan masak, kapan daun akan gugur. Hormon tumbuh adalah senyawa kimia yang sangat aktif. Hormon yang memengaruhi pertumbuhan sehingga sering disebut hormon zat tumbuh. Hormon tumbuh pada tumbuhan ditemukan oleh ahli botani yang berasal dari belanda yang bernama Went, tahun 1926. Hormon tumbuh tumbuhan memiliki banyak jenis. Hormon tumbuhan adalah auksin, giberelin, sitokinin, gas etilen dan asam absisat serta kalin (Sitompul \& Guritno, 1995).

Fungsi hormon auksin adalah merangsang perpanjangan sel, merangsang pembentukan bunga dan buah, merangsang pemanjangan titik buah, mempengaruhi pembengkokan batang, merangsang pembentukan akar lateral, dan merangsang terjadinya proses diferensiasi. Sedangkan fungsi giberelin adalah: mempengaruhi pemanjangan dan pembelahan sel, memengaruhi perkembangan embrio dan kecambah, menghambat pembentukan biji, mempengaruhi pemanjangan batang, dan memengaruhi pertumbuhan dan perkembangan akar, daun, bunga, dan bunga (Siregar, 2009).

Auksin berfungsi dalam pengembangan sel, pertumbuhan akar, fototropisme, geotropisme, partenokarpi, apikal dominan, pembentukan kalus, respirasi (Abidin, 1993). Pembentukan akar pada stek merupakan akibat kegiatan rizokalin, sedangkan rizokalin termasuk dalam kelompok auksin. ZPT eksogen pada kelompok auksin adalah IPA (Indole Propionic Acid) dan IBA (Indole Butiric Acid). Mekanisme kerja auksin yaitu mempengaruhi pelenturan dinding sel, sehingga air masuk secara osmosis dan memacu pemanjangan sel. Selanjutnya ada kerja sama antara auksin dan giberelin yang memacu perkembangan jaringan pembuluh dan mendorong pembelahan sel sehingga mendorong pembesaran batang (Rusmin, Suwarno, \& Darwati, 2011). Kerjasama auksin dan sitokonin dengan konsentrasi 2,5 ppm dan 2,75 ppm dibuktikan dengan adanya peningkatan persentase perkecambahan pada bibit kamandrah (Croton tiglium L.) yaitu tanaman yang memiliki daya racun terhadap larva Aedes Aegypti (Tjokrowardojo, Rosman, \& Pradono, 2009).

Beberapa bahan alami yang dapat digunakan sebagai bahan auksin dan giberelin organik adalah rebung, bawang merah, air kelapa, kecambah (tauge), bonggol pisang, pucuk daun-daunan, susu segar, kuning telur ayam kampung, bekicot, tetes tebu, dan lain sebagainya (Batori, 2013). Aplikasi berbagai ekstrak sebagai sumber ZPT alami memberikan pengaruh terhadap daya kecambah, tinggi bibit umur 30 HST, 37, 44 HST, 51 HST, dan jumlah daun 51 hari HST pada 
kemiri sunan. Aplikasi ekstrak bonggol pisang sebagai sumber ZPT dicampur air kelapa memberikan hasil paling baik terhadap semua variabel yang diamati. Ekstrak rebung bambu dan ekstrak umbi bawang merah mempunyai potensi untuk diaplikasikan pada benih untuk mendapatkan bibit kemiri sunan yang baik. Bahan-bahan zat pengatur tumbuh difermentasikan dengan dekomposer MBIO selama 14 hari sebelum digunakan sampai terbentuk ekstrak. Kemudian pada pelak-sanaannya digunakan konsentrasi $40 \mathrm{ml} \mathrm{L-1}$. Selanjutnya adalah merendam biji bernas kemiri sunan dalam ekstrak bahan ZPT alami selama 24 jam. Kemudian menebar biji pada bak persemaian dan dilakukan pengamatan perkecambahan dan pertum-buhan pembibitan (Kurniati, Sudartini, \& Hidayat, 2017).

Penelitian Purwitasari (2004) menghasilkan pertumbuhan akar stek pucuk berbagai varietas krisan dengan pemberian perasan bawang merah konsentrasi 30\% selama 15 menit. Dikemukakan Ichsanudin (2013), bahwa perlakuan konsentrasi ekstrak umbi bawang merah terhadap bibit pepaya (Carica papaya L), menunjukkan bahwa konsentrasi ekstrak umbi bawang merah $15 \mathrm{ml} \mathrm{L-1}$ memberikan hasil tertinggi dibandingkan konsentrasi $5 \mathrm{ml} \mathrm{L-1,10} \mathrm{ml} \mathrm{L-1} \mathrm{dan} 20 \mathrm{ml}$ L-1 pada parameter kecepatan berkecambah, daya kecambah, panjang akar, diameter batang, tinggi bibit, luas daun, berat segar dan berat kering bibit. Menurut Marfirani, Rahayu, dan Ratnasari (2009), pada bawang merah terdapat senyawa yang disebut allin yang kemudian akan berubah menjadi senyawa thiosulfinat seperti allicin. Allicin dengan thiamin (vitamin B) membentuk allithiamin yang memperlancar metabolisme pada jaringan tumbuhan. Penelitian Mardaleni dan Sutriana (2014) menunjukkan bahwa pemberian ekstrak rebung 4,5 ml L-1 air memberikan pengaruh baik terhadap tinggi, dan bobot polong kacang kacang hijau.

Hasil penelitian memperlihatkan bahwa penggunaan air kelapa muda sebagai ZPT dapat meningkatkan pertumbuhan dan produksi tanaman. Penelitian yang dilakukan Ratnawati, Saputra, dan Yoseva (2013) menunjukkan bahwa perendaman bahan stek kakao dalam air kelapa selama 18 jam mem-berikan hasil yang tinggi. Selanjutnya Marpaung, Udiarto, Lukman, dan Hardiyantom (2019) menunjukkan hasil penelitian bahwa air kelapa 50\% meng hasilkan panjang tunas, jumlah daun, panjang akar, dan bobot basah akar lebih tinggi pada buah tin. Pemberian beberapa jenis ekstrak tanaman (bonggol pisang, rebung dan campuran) sebagai zat pengatur tumbuh dan rasio amelioran terhadap pertumbuhan dan produksi padi varietas Inpari 12 di lahan gambut oleh Septari, Nelvia, dan Amri (2013), hasilnya menunjukkan bahwa ekstrak bonggol pisang menghasilkan tanaman yang lebih tinggi daripada rebung dan campurannya.

\section{KESIMPULAN}

Melalui serangkaian kegiatan pelatihan, dan pendampingan pembuatan dan penggunaan auksin dan giberelin organik di Kelompok Tani Sumber Urip-1, maka mitra telah menguasai (1) metode pembuatan auksin dan giberelin organik dan (2) metode penggunaan auksin dan giberelin organik. Produk auksin dan giberelin diberi merk "Vignauksin" (dari taoge), "Fulicauksin" (dari bekicot), dan "Zeaberelin" (dari jagung). Penguasaan mitra terhadap metode pembuatan dan penggunaan auksin dan giberelin organik akan mendukung upaya pertanian organik yang merupakan perwujudan pertanian berkelanjutan.

Berdasarakan hasil kegiatan pelatihan dan pendampingan pembuatan serta penggunaan auksin dan giberelin, maka dapat diberikan rekomendasi bahwa sebagai upaya mengoptimalkan kemanfaatan program untuk mitra, selaanjutnya dapat dilakukan: (1) Pendampingan pemasaran auksin dan giberelin dari bahan lokal dengan memanfaatkan media sosial atau e-commerce, melalui pedagang tanaman hias, dan melalui kelompok tani organik dan (2) Perancangan dan pendampingan analisis ekonomi produksi auksin dan giberelin organik. Kegiatan ini pun dapat direplikasi di berbagai tempat atau daerah, terutama yang memiliki program pertanian organik.

\section{REFERENSI}

Aertsens, J., Verbeke, W., Mondelaers, K., \& van Huylenbroeck, G. (2009). Personal determinants of organic food consumption: A review. In British Food Journal (Vol. 111). https://doi.org/10.1108/00070700910992961

Batori, I. (2013). Bahan nabati auksin dan giberelin organik. Jakarta: Publisia.

Budiyanto, M. A. K. (2007). Persepsi masyarakat tentang pertanian hortikultura organik di Kabupaten Malang. Malang: Universitas Muhammadiyah Malang.

Budiyanto, M. A. K. (2013). Model pengembangan produksi pangan organik. Malang: Universitas Muhammadiyah Malang.

Budiyanto, M. A. K., Waluyo, L., \& Rahadjanto, A. (2020). Pendampingan pembuatan akarisida organik di kelompok tani Sumber Urip-1 Desa Wonorejo Kecamatan Poncokusumo Kabupaten Malang. International Journal of Community Service Learning, 4(1), 10. https://doi.org/10.23887/ijcsl.v4i1.19660

Diwanti, D. P. (2018). Pengembangan potensi masyarakat Dusun Klajuran melalui pemberdayaan pertanian organik. Jurnal Berdikari, 6(1), 29-39.

Hamka, E., Mahmud, A., Bubun, R. L., Tamtama, A., Kendari, U. M., Pertanian, F., \& Kendari, U. M. (2018). Sistem organik untuk pengembangan pertanian organik di Desa Lamomea Kabupaten Konawe Selatan. Jurnal Dedikasi, 15(1), 62-70. https://doi.org/10.22219/dedikasi.v15i0.6441 
Hatta, A. M., Jaelani, L. M., \& Taufany, F. (2020). Panduan pengabdian kepada masyarakat (Abmas) dana ITS tahun 2020. Surabaya: Direktorat Riset dan Pengabdian kepada Masyarakat, Institut Teknologi Sepuluh Nopember.

Ichsanudin, F. N. (2013). Pengaruh konsentrasi jus umbi bawang merah terhadap perkecambahan dan pertumbuhan awal bibit Carica papaya L. UNS-F. Pertanian.

Indriana, H., A Kinseng, R., \& Adriana, G. (2016). Dinamika kelembagaan pertanian organik menuju pembangunan berkelanjutan. Sodality: Jurnal Sosiologi Pedesaan, 4(2), 1-17. https://doi.org/10.22500/sodality.v4i2.13652

Ishartono, I., \& Raharjo, S. T. (2016). Sustainable development goals (SDGs) dan pengentasan kemiskinan. Share: Social Work Journal, 6(2), 154-272. https://doi.org/10.24198/share.v6i2.13198

Jolly, D. A., \& Norris, K. (1991). Marketing prospects for organic and pesticide-free produce. American Journal of Alternative Agriculture, 6(4), 174-179.

Juned, M., Kusumastuti, R. D., \& Darmastuti, S. (2015). Penguatan peran pemuda dalam pencapaian tujuan ketiga Sustainable Development Goals (SDGs) di Karang Taruna Keluarahan Serua, Bojongsari, Depok. Prosiding Seminar Hasil Pengabdian Kepada Masyarakat, 1-7. Jakarta: Universitas Pembangunan Nasional "Veteran" Jakarta.

Kurniati, F., Sudartini, T., \& Hidayat, D. (2017). Aplikasi berbagai bahan ZPT alami untuk meningkatkan pertumbuhan bibit kemiri sunan (Reutealis trisperma (Blanco) Airy Shaw). Jurnal Agro, 4(1), 40-49. https://doi.org/10.15575/1307

Mardaleni, M., \& Sutriana, S. (2014). Pemberian ekstrak rebung dan pupuk hormon tanaman unggul terhadap pertumbuhan dan produksi kacang hijau (Vigna radiata L). Jurnal Dinamika Pertanian, 29(1), 45-56. Retrieved from https://journal.uir.ac.id/index.php/dinamikapertanian/article/view/859/538

Marfirani, M., Rahayu, Y. S., \& Ratnasari, E. (2009). Pengaruh pemberian berbagai konsentrasi filtrat umbi bawang merah dan Rootone-F terhadap pertumbuhan stek melati "Rato Ebu." LenteraBio, 3(1), 73-76.

Marpaung, A. E., Udiarto, B. K., Lukman, L., \& Hardiyanto, N. (2019). Potensi pemanfaatan formulasi pupuk organik sumber daya lokal untuk budidaya kubis. Jurnal Hortikultura, 28(2), 191-201. https://doi.org/10.21082/jhort.v28n2.2018.p191-200

Mollier, L., Seyler, F., Chotte, J.-L., \& Ringler, C. (2018). SDG2 End hunger, achieve food security and improved nutrition, and promote sustainable agriculture. In Atlas of Sustainable Development Goals 2018: From World Development Indicators (pp. 34-80). https://doi.org/10.1596/978-1-4648-1250-7_ch2

Mustafa, D. (2018). Penerapan kimia hijau untuk menjamin keamanan pangan. Seminar Nasional FMIPA Universitas Terbuka 2018 Minum, 25-50. Jakarta: Universitas Terbuka.

Ngoyo, M. F. (2015). Mengawal Sustainable Development Goals (SDGs); Meluruskan Orientasi Pembangunan yang Berkeadilan. Sosioreligius, /(1), 77-88. Retrieved from http://journal.uinalauddin.ac.id/index.php/Sosioreligius/article/view/4525

Nhemachena, C., Matchaya, G., Nhemachena, C. R., Karuaihe, S., Muchara, B., \& Nhlengethwa, S. (2018). Measuring baseline agriculture-related sustainable development goals index for Southern Africa. Sustainability (Switzerland), 10(3), 1-16. https://doi.org/10.3390/su10030849

Panuluh, S., \& Fitri, M. R. (2016). Perkembangan pelaksanaan Sustainable Development Goals (SDGs) di Indonesia. In Biefing Paper 02. Retrieved from http://www.sdg2030indonesia.org/an-component/media/uploadbook/Briefing_paper_No_1_SDGS_-2016-Meila_Sekar.pdf

Pramita, Y., Wandansari, N. R., \& Salim, A. (2018). Aplikasi pupuk organik dan zat pengatur tumbuh dalam peningkatan produktivitas tanah dan tanaman. Seminar Nasional Program Studi Agribisnis Fakultas Pertanian Universitas Jember, 673-684. Jember: Program Studi Agribisnis Fakultas Pertanian Universitas Jember.

Prihandarini, R. (2009). Potensi pengembangan pertanian organik. Jakarta: Departemen Pertanian.

Prihanta, W., Zainuri, A. M., Hartini, R., Syarifuddin, A., \& Patma, T. S. (2020). Pantai Taman-Pacitan ecotourism development: Conservation and community empowerment orientation. Journal of Community Service and Empowerment, 1(1), 1-16. https://doi.org/10.22219/jcse.v1i1.11515

Purwitasari, W. (2004). Pengaruh perasan bawang merah (Allium ascalonicum L.) terhadap pertumbuhan akar stek pucuk krisan (Chrysanthemum sp.). FMIPA Universitas Diponegoro.

Puu, Y. M. S. W., Saga, A. J. P. A., Djata, B. T., \& Mutiara, C. (2019). Pemberdayaan masyarakat petani dalam pengelolaan pupuk dan pestisida organik dari tanaman lokal di Desa Wolofeo Kecamatan Detusoko Kabupaten Ende. PRIMA: Journal of Community Empowering and Services, 3(2), 43-49. https://doi.org/10.20961/prima.v3i2.39203

Rampa, F., Dekeyser, K., Alders, R., \& Dar, O. (2019). The global institutional landscape of food and agriculture: How to achieve SDG 2. In ECDPM Discussion Paper No. 265.

Ratnawati, R., Saputra, S. I., \& Yoseva, S. (2013). Waktu perendaman benih dengan air kelapa muda terhadap pertumbuhan bibit kakao (Theobroma cacao L.). Pekanbaru.

Rusmin, D., Suwarno, F. C., \& Darwati, I. (2011). Pengaruh pemberian GA3 pada berbagai konsentrasi dan lama imbibisi terhadap peningkatan viabilitas benih purwoceng (Pimpinella pruatjan Molk.). Jurnal Penelitian Tanaman Industri, 17(3), 89-94. https://doi.org/10.21082/jlittri.v17n3.2011.89-94

Septari, Y., Nelvia, N., \& Amri, A. I. (2013). Pengaruh pemberian beberapa jenis ekstrak tanaman sebagai ZPT dan rasio amelioran terhadap pertumbuhan dan produksi padi varietas Inpari 12 di lahan gambut. Pekanbaru. 
Shofi, M., \& Putri, M. P. (2020). Training on making cendol starch using blue natural dyes extracted from telang flower essence. Journal of Community Service and Empowerment, 1(1), 25-30. https://doi.org/10.22219/jcse.v1i1.11514

Siregar, A. S. (2009). Inventarisasi tanaman sukun (Arthocarpus communis) pada berbagai ketinggian di Sumatera Utara. Departemen Kehutanan Fakultas Pertanian USU.

Sitompul, S. M., \& Guritno, B. (1995). Analisis pertumbuhan tanaman. Yogyakarta: Gadjah Mada University Press.

Susanti, N. (2018). Pengembangan community based economic development sebagai upaya pencapaian Sustainable Development Goals (SDGs) 2030 (Studi deskriptif pada kelompok usaha peningkatan pendapatan keluarga sejahtera (UPPKS) di Kecamatan Peterongan Kabupaten Jombang). Kebijakan Dan Manajemen Publik, 6(3), 1-9.

Tjokrowardojo, A. S., Rosman, R., \& Pradono, D. I. (2009). Pengaruh zat pengatur tumbuh terhadap perkecambahan benih dan pertumbuhan bibit kamandrah (Croton tiglium L.). Jurnal Agrotropika, 14(2), 55-60.

Wahyuningsih, W. (2018). Millenium Develompent Goals (MDGs) dan Sustainable Development Goals (SDGs) dalam kesejahteraansosial. Bisma Jurnal Bisnis Dan Manajemen, 11(3), 390-399.

https://doi.org/10.19184/bisma.v11i3.6479 